\title{
PELAYANAN REKAM MEDIS RAWAT JALAN PADA MASA PANDEMI COVID-19 DI KLINIK X KOTA BANDUNG
}

\author{
Anisa Nuraulia ${ }^{*}$, Sali Setiatin ${ }^{2}$, Andzara Aulia ${ }^{3}$ \\ Rekam Medis dan Informasi Kesehatan, Politeknik Piksi Ganesha ${ }^{1,2,3}$ \\ anisanuraulia12081@gmail.com*1, salisetiatin@gmail.com², andzaraaulia@gmail.com ${ }^{3}$
}

Received: 28-08-2021

Revised : 17-09-2021

Accepted: 24-09-2021

\begin{abstract}
Abstrak
Latar Belakang: Penelitian ini bertujuan untuk mendeskripsikan tentang pelayanan rekam medis rawat jalan pada masa pandemi COVID-19 di Klinik X. Dimana bagian pendaftaran merupakan bagian yang pertama di temui oleh pasien saat pasien datang ke pelayanan kesehatan. Rekam medis tersebut merupakan pelayanan yang berfungsi untuk mendukung proses keperawatan pasien mencakup isi dan informasi-informasi data pasien
\end{abstract}

Tujuan:. Tujuan penelitian ini untuk mengetahui pelayanan rekam medis pada masa pandemi COVID-19.

Metode: Metode jenis penelitiannya yaitu metode kualititaf penelitian ini di lakukan dengan cara observasi langsung dan wawancara kepada petugas rekam medis dan kepala unit rekam medis.

Hasil: Hasil pelayanan rekam medis di Klinik X Kota Bandung pada masa pandemi sudah menuju digitalisasi melakukan pendaftaran dan konsultasi online via whatsapp tapi masih ada kendalanya yaitu pendaftaran online pada penerimaan pendaftarannya terlambat, konsultasi online pelayanannya terlambat dan Standar Operasional penyimpanan rekam medisnya belum memenuhi standar karena tidak adanya tracer, bon peminjaman, buku register dan out guide sehingga dokumen rekam medis yang tidak ada di rak penyimpanan, pasien mendapatkan pelayannya akan terlambat. Kesimpulan Klinik $\mathrm{X}$ ini sudah menuju digitalisasi namun masih ada beberapa kendalanya dan perlu di perbaiki lagi.

Kesimpulan: Pada penyimpanan rekam medis Klinik X tidak menggunakan tracer, bon peminjaman dan out guide oleh karena itu petugas sering mengalami kesulitan dalam mencari dokumen rekam medis pasien yang hilang di rak penyimpanan sehingga pasien mendapatakan pelayanan selanjutnya akan terlambat. Standar Operasional Prosedur (SOP) di Klinik X ini belum memenuhi standar atau belum efektif karena masih ada beberapa bagian yang belum lengkap.

Kata kunci: rekam medis; efektivitas; pelayanan kesehatan. 


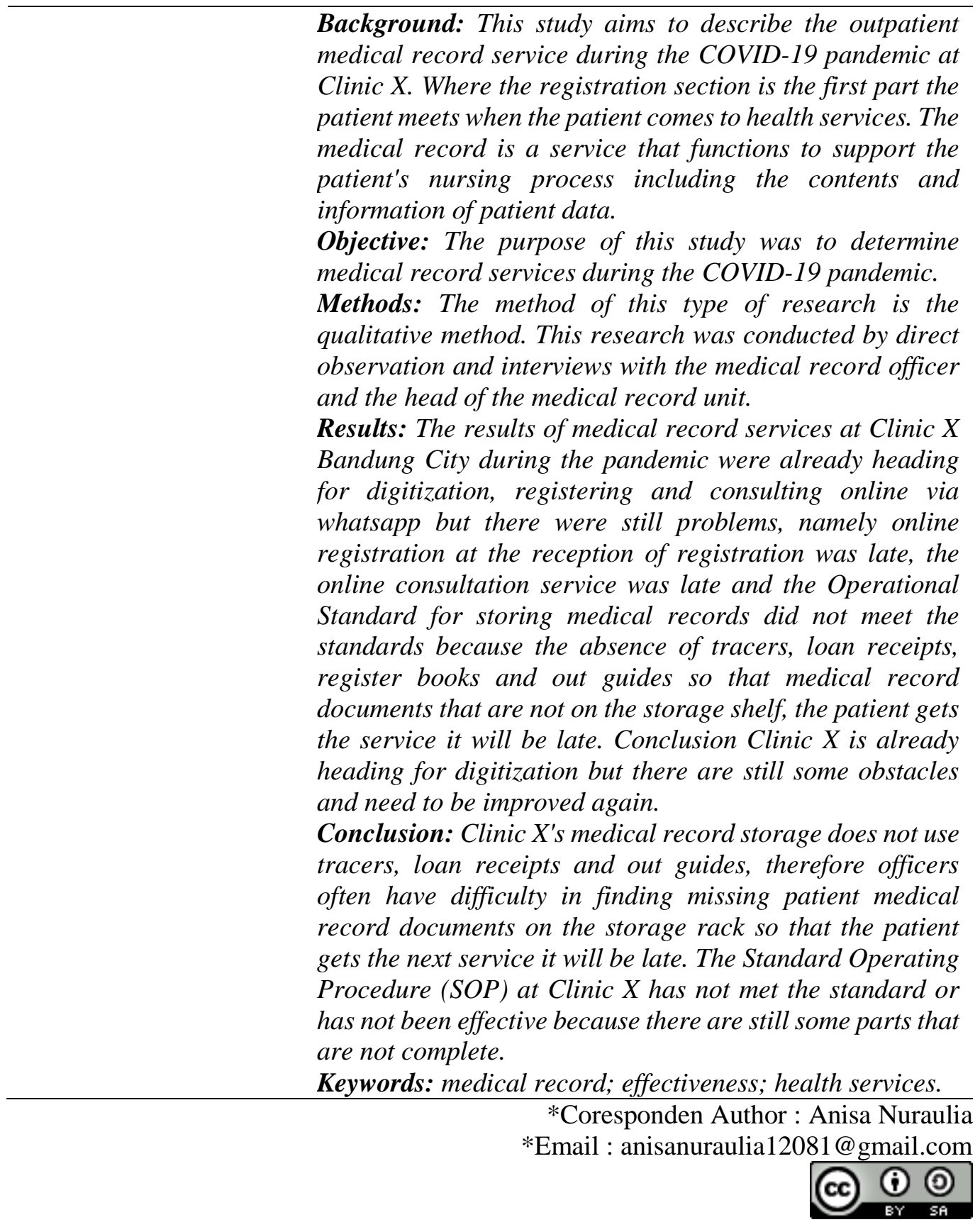

\section{PENDAHULUAN}

Menurut situs World Health Organization (WHO) Corona virus sebagai Pandemi karena virus ini sangat meresahkan dunia karena jumlah kasus yang selalu meningkat dan virus ini merupakan kumpulan virus yang menyerang pada tubuh manusia sehingga bisa mengakibatkan terjadinya infeksi saluran pernapasan. Orang yang mudah tertular penyakit virus COVID-19 adalah lansia, orang yang mempunyai riwayat penyakit asma, daya imun tubuh yang kurang dan orang yang terkena COVID-19 akan ada yang mengalami gejala ringan, gejala berat ataupun sedang jika mengalami gelajala berat maka harus membutuhkan penanganan khusus sedangkan jika mengalami gejala ringan dan sedang cukup melakukan isolasi mandiri selama 2 minggu (Organization, 2020). 
Menurut (Asriati, 2021) Virus ini sangat menular melalui percikan air liur, batuk bersin dan barang yang sudah terkontaminasi oleh seorang yang terinfeksi COVID-19. Penyakit ini awalnya berada di China pada akhir tahun 2019 bulan Desember dan masuk ke Indonesia pada pertengahan bulan Maret 2020 awalnya menyerang 2 orang makin hari pasien semakin meningkat yang terinfeksi COVID-19 sampai sekarang oleh karena itu (Irianti, Fadly, and Nursta'adah, 2021) di Indonesia selama pandemic resmi diadakannya pembatas social berskala besar (PSBB) dengan dikeluarkannya kebijakan PSBB banyak berdampak pada kehidupan sehari - hari masyarakat, termasuk juga dengan kesulitan masyarakat untuk mendapatkan askes kesehatan. PSBB ini di adakan pada akhir bulan maret 2020 sampai sekarang untuk memutuskan mata rantai penyebaran COVID-19.

Permasalahan yang ada di Klinik X Kota Bandung selama masa pandemi COVID19 yaitu, pada pelayanan pendaftaran online penerimaan pasiennya terlambat oleh karena itu pasien harus sabar, dan pelayanan konsultasi online tidak menggunakan sistem no antrian sehingga pelayanan pasiennya akan terlambat oleh karena itu pasien harus sabar dalam mendapatkan pelayanan dari dokter.

Rekam Medis juga dapat diartikan sebagai keterangan baik yang tertulis maupun yang terekam tentang identitas pasien, anamnesa, penentuan hasil fisik dan laboratorium, diagnosa dan segala tindakan medis yang diberikan kepada pasien dan pengobatan baik yang melakukan rawat jalan, rawat inap maupun yang mendapatakan pelayanan rawat gawat darurat. Oleh karena itu kelengkapan rekam medis harus sesuai dengan prosedur rekam medis agar rekam medis pasien menjadi lebih akurat dan lengkap (Hidayati \& Dewi, 2018).

Menurut (Ali and et al, 2018) pelayanan rawat jalan merupakan salah satu unit di puskesmas untuk melayanani pasien yang berobat jalan ke fasilitas pelayanan kesehatan (fasyankes) dan tidak lebih dari 24 jam mendapatkan pelayanan, termasuk seluruh prosedur diagnostic dan terapeutik. Di waktu yang akan datang, rawat jalan merupakan bagian pelayanan kesehatan terbesar di Puskesmas. Pertumbuhan yang cepat dari rawat jalan dapat ditentukan oleh tiga faktor yaitu : 1) penekanan biaya untuk mengontrol peningkatan harga perawatan kesehatan dibandingkan dengan rawat inap 2) Peningkatan kemampuan dan sistem reimbursement merupakan prosedur pelayanan untuk di rawat jalan 3) Merupakan perkembangan dengan secara terus menerus dari teknologi tinggi untuk pelayanan rawat jalan akan menyebabkan pertumbuhan rawat jalan.

Menurut (PERMENKES RI No 269/MENKES/PER/III/2008, 2008) yaitu : ayat 2 pasal 3 rekam medis adalah berkas yang berisi identitas, anamnesa, penentuan fisik, laboratorium, diagnosa dan tindakan medis. Ayat 2 pasal 2 terhadap pasien yang dicatat baik secara tertulis maupun secara elektronik (Ismail, 2020). Pengertian rekam medis merupakan suatu sistem penyelenggaran dari mulai pencatatan, pelayanan dan tindakan yang didapatkan oleh pasien, hingga penyimpanan dokumen rekam medis hingga pengeluaran dokumen rekam medis pasien dari penyimpan rekam medis guna untuk kepentingan sendiri maupun untuk keperluan lain.

Rekam medis dalam penatalaksanaanya tidak akan terlepas dari media sebagai tempat penyimpanan atau menuliskan sebagai bukti dan dokumen pelayanan kesehatan yang diberikan kepada pasien, menurut (Permenkes, 2008) tentang rekam medis tercantum pada pasal (1) ayat (1) berbunyi ; yaitu rekam medis merupakan berkas yang berisi catatan dan dokumen tentang identitas pasien, pemeriksaan, pengobatan, tindakan dan pelayanan yang diberikan kepada pasien. Oleh karena itu rekam medis merupakan milik pasien dan harus di jaga kerahasiaannya tidak boleh disebarluaskan tetapi rekam medis juga merupakan sebagai alat bukti pengadilan untuk persidangan.

Isi rekam medis merupakan sumber data atau informasi data dari rekam medis pasien sehingga jika terjadi ketidaklengkapan rekam medis pasien dapat memberikan dampak yang tidak baik bagi proses pelayanan kesehatan kepada pasien yang nantinya akan berdampak pada mutu pelayanan pasien, oleh karena itu data rekam medis pasien di Rumah Sakit harus mengandung informasi yang akurat dan lengkap karena harus 
diperlukan pencatatan dan pelaporan dengan secara rutin untuk kesembuhan pasien (Wibowo et al, 2017). Disamping itu rekam medis pasien yang tidak akurat, analisis terhadap riwayat penyakit serta tindakan medis tidak dapat dilakukan secara baik akan berdampak pada keselamatan pasien.

Pelayanan rekam medis mulai dari pendaftaran, keperawatan, sampai pengembalian dokumen rekam medis ke ruangan penyimpan rekam medis. Batas waktu pengembalian rekam medis 1x24 jam dan setiap Klinik atau rumah sakit harus mempunyai rekam medis guna untuk memberikan pelayanan yang akurat untuk menghasilkan pelayanan rekam medis yang akurat dan lengkap kita harus memperoleh kerja sama antara perawat, bidan, dokter dan tenaga lainnya. Karena kalau isi rekam medis tidak lengkap maka proses pelayanannya tidak akurat sehingga mutu pelayanannya kurang baik (Rendarti, 2019).

Pelayanan rekam medis merupakan salah satu pelayanan penunjang medis yang menjadi dasar penilaian terhadap mutu pelayanan medis rumah sakit (Nuraini, 2015). Pelayanan rekam medis merupakan pelayanan pertama yang diberikan kepada pasien dari mulai pasien di terimanya berobat dan mendapatakan pelayanan yang baik hingga penyimpanan dokumen rekam medisnya. Selama masa pandemi COVID-19 di Klinik X Kota Bandung pelayanannya sudah menggunakan digitalisasi yaitu dengan melakukan pendaftaran online lewat whatsapp untuk mengurangi antrian panjang di masa pandemi COVID-19, dan bagi pasien yang tidak bisa datang ke Klinik juga bisa melakukan konsultasi online lewat whatsapp dengan dokter. Menurut (Hukum et al, 2021) selama masa pandemi dengan adanya konsultasi online atau yang disebut juga telemedicine itu yaitu untuk mengurangi kunjungan pasien ke fasilitas pelayanan kesehatan (fasyankes) di masa pandemi untuk menghindari COVID-19 yang semakin luas. Pelayanan telemedicine merupakan pelayanan kesehatan yang diberikan oleh dokter atau petugas tenaga kesehatan yang memiliki surat ijin praktek (SIP) di ruangan lingkup (fasyankes). Di Indonesia layanan konsultasi online di atur dalam (Kemenkes, 2019). Permenkes ini berisi tentang penyelenggaraan pelayanan telemedicine melalui antar fasilitas pelayanan kesehatan atau yang disebut juga fasyankes.

Telemedicine menurut (Kemenkes, 2019) tercantum pada pasal (1) ayat (1) yang berbunyi : Telemedicine adalah pemberian pelayanan kesehatan jarak jauh oleh profesional tenaga kesehatan dengan menggunakan teknologi informasi dan komunikasi, meliputi pertukaran informasi diagnosis, pengobatan, pencegahan penyakit dan cedera, penelitian, evaluasi, dan pendidikan berkelanjutan penyediaan layanan kesehatan untuk kepentingan peningkatan kesehatan individu dan kesehatan masyarakat.

Hasil studi dari pendahuluan yang di dapat di Klinik X Kota Bandung ini terjadi pengurang jam kerja untuk pelayanan kesehatan di masa Pandemi COVID-19 dan di masa pandemi COVID-19 jumlah pasien yang berobat ke Klinik X ini terjadi penurunan, begitu juga di masa Pandemi ini untuk mengurangi antrian panjang Klinik $\mathrm{X}$ ini memberikan pelayanan konsultasi online atau melakukan pendaftaran online bisa Whatsapp untuk memutuskan mata rantai penyebaran COVID-19. Hasil dari wawancara kepada petugas rekam medis dan kepala Unit Kerja Rekam Medis pada masa pandemi COVID-19 banyak perubahan pada pelayanan .

Dari hasil penelitian pendahuluan tersebut yang di dapat di Klinik X Kota Bandung ini selama masa pandemi mengurangi jam pelayanan kesehatan dan jumlah pasien yang melakukan berobat jalan ke Klinik X Kota Bandung terjadi penurun di masa pandemi COVID-19. Untuk mengurangi antrian panjang Klinik X Kota Bandung memberikan pelayanan konsultasi online dan pendaftaran online lewat whatsapp untuk memutuskan mata rantai penyebaran COVID-19.

Dengan adanya tujuan penelitian ini untuk menggetahui tentang keadaan pelayanan rekam medis rawat jalan pada masa pandemi COVID-19 di Klinik X Kota Bandung. Sehingga penulis. 


\section{METODE PENELITIAN}

Metode penelitian yang di gunakan yaitu menggunakan metode kualitatif (Creswell, 2016). Teknik pengumpulan data yang di gunakan yaitu dengan wawancara dan observasi untuk mengetahui pelayanan rekam medis rawat jalan pada masa pandemi COVID-19. Metode penelitian di laksanakan dengan cara observasi langsung ke Klinik X Kota Bandung pada bulan April - Mei 2021. Penelitian yang akan ditelitinya di Pelayanan rekam medis rawat jalan pada masa pandemi COVID-19 yaitu pelayanan kosultasi online, pendaftaran via online via whatsapp dan penyimpanan rekam medis. Metode mengumpulkan data yaitu dengan cara observasi, wawancara ke pada petugas rekam medis bagian pendaftaran, petugas bagian filling dan kepala Unit Kerja Rekam Medis.

\section{HASIL DAN PEMBAHASAN}

\section{A. Hasil Penelitian}

Jumlah Pasien Rawat Jalan Pada Masa Pandemi COVID-19

Tabel 1. Hasil Kunjungan Jumlah Pasien Bulan April 2021

\begin{tabular}{llc}
\hline No & Pelayanan Kesehatan Pasien Rawat Jalan & JumlahPasien \\
\hline 1 & Layanan Kesehatan Gigi dan Mulut Pukul 08.00 & 380 \\
\hline 2 & Layanan Kesehatan Gigi dan Mulut Online & 419 \\
\hline 3 & Layanan Kesehatan Umum Pukul 08.00 & 1.637 \\
\hline 4 & Layanan Kesehatan Umum Pukul 11.00 & 1.135 \\
\hline 5 & Layanan Kesehatan Umum Pukul 14.00 & 729 \\
\hline 6 & Layanan Kesehatan Umum Konsultasi Online & 1.574 \\
\hline 7 & Ruang Tindakan & 127 \\
\hline & Jumlah Total Kunjungan Pasien Bulan April 2021 & 6.001 \\
\hline
\end{tabular}

Sumber : data di olah 2021

Berdasarkan hasil tabel 1 diatas merupakan jumlah kunjungan pelayanan pasien rawat jalan selama masa pandemi. Pada bulan April 2021 jumlah pelayanan pasien rawat jalan lebih banyak pasien yang datang ke klinik di bandingkan dengan yang konsultasi online dan jumlah kunjungan selama 1 bulan terjadi peningkatan.

Tabel 2. Hasil Jumlah Kunjungan Pasien Bulan Mei 2021

\begin{tabular}{llc}
\hline No & Pelayanan Kesehatan Pasien Rawat Jalan & Jumlah Pasien \\
\hline 1 & Layanan Kesehatan Gigi dan Mulut Pukul 08.00 & 328 \\
\hline 2 & Layanan Kesehatan Gigi dan Mulut Online & 350 \\
\hline 3 & Layanan Kesehatan Umum Pukul 08.00 & 1.409 \\
\hline 4 & Layanan Kesehatan Umum Pukul 11.00 & 1.052 \\
\hline 5 & Layanan Kesehatan Umum Pukul 14.00 & 662 \\
\hline 6 & Layanan Kesehatan Umum Konsultasi Online & 1.533 \\
\hline 7 & Ruang Tindakan & 106 \\
\hline & Jumlah Total Kunjungan Pasien Bulan Mei 2021 & 5.440 \\
\hline
\end{tabular}

Sumber : data di olah 2021

Berdasarkan hasil tabel 2 diatas merupakan jumlah kunjungan pelayanan pasien di bulan Mei 2021 selama masi Pandemi. Pada bulan Mei 2021 jumlah kunjungan pasien terjadi penurunan di bandingkan dengan yang bulan Mei. 
Penelitiaan ini di lakukan dengan cara observasi langsung ke Klinik X Kota Bandung pada bulan April-Mei 2021. Pelayanan rekam medis rawat jalan pada masa pandemi COVID-19 di Klinik X ini sudah menggunakan digitalisasi yaitu bisa daftar online via whatsapp untuk mengurangi antrian panjang. Selama masa pandemi Klinik X memberikan pelayanan mulai dari jam 07.30 pagi - 17.00 sore sebelum masa pandemi Klinik X memberikan pelayanan mulai dari jam 07.30 pagi - 20.00 malam. Klinik X juga selama masa pandemi sudah menggunakan digitalisai bisa melakukan pendaftaran online lewat whatsapp untuk mengurangi antrian yang cukup panjang, pasien yang tidak bisa dating ke Klinik juga bisa melakukan konsultasi online (Telemedicine) lewat whatsapp dengan dokter. Dan pasien yang daftar langsung datang ke Klinik X Kota Bandung untuk berobat masih dilayanani tetapi pasien harus screening terlebih dahulu baru setelah itu bisa di daftarkan oleh petugas pendaftaran untuk berobat. Hasil penelitian ini yaitu :

Pelayanan pendaftaran online

Pada pelayanan penerimaan pendaftaran online masih ada masih ada beberapa pasien mengeluh yang datang ke Klinik X tidak mendapatkan pelayanan pada pendaftaran online dan penerimaanya terlambat.

Pelayanan konsultasi online

Pasien yang tidak bisa datang ke Klinik $\mathrm{X}$ juga bisa melakukan konsultasi online via whatsapp dengan dokter. Pada pelayanan konsultasi online pelayanannya terlambat karena dokter harus merespon pasien dari bawah dan di sistem pelayanan konsultasi online ini tidak menggunakan nomor antrian sehingga pasien harus sabar dalam mendapatkan pelayanan dari dokter. Penyimpanan rekam medis yang belum memenuhi standar operasional prosedur.

\section{B. Pembahasan}

Hasil wawancaranya yaitu pada pelayanan rekam medis selama masa pandemi Klinik X sudah menggunakan digitalisasi pendaftaran lewat whatsapp untuk mengurangi antrian yang cukup panjang pada masa pandemic. Pada pelayanan pendaptaran online penerimaan pasiennnya terlambat karena masih ada beberapa pasien yang mengeluh datang ke Klinik tidak mendapatkan pelayanan pendaftaran online. Karena Klinik X pada pelayanan pendaftaran online di whastapp tidak menggunakan sistem no antrian sehingga pasien harus sabar untuk mendapatakan pelayanan penerimaan pendaftaran online dan yang daftar juga banyak. Karena disini tidak menggunakan sistem no antrian maka petugas pendaftaran online merespon chat pasien dari sehingga kalau pasien ngechat terus maka pasienpun mendapatakan pelayanan penerimaan pendaftaran online akan terlambat. Oleh karena itu Klinik X harus memperbaikinya dengan menggunakan aplikasi pada pelayanan pendaftaran online dan konsultasi online supaya no antrian pasien jelas.

\section{Prosedur Pelayanan Pendaftaran Online}

Pasien WA ke no Pendaftaran Klinik, pada saat pasien daftar online untuk berobat pasien mengirimkan kartu BPJS nya untuk di daftarkan dan pasien harus sabar untuk mendapatkan balasan dari petugas pendaftaran. Pasien di daftarkan, setelah mendapatkan balasan dari petugas pendaftaran pasien akan di daftarkan kepada dokter yang praktek sesuai jadwal dan no antrian akan di kirimkan dan di beritahukan untuk mengambil no antrian di bagian pendaftaran. Pasien datang ke Klinik, pasien terlebih dahulu di screening sebelum mengambil no antrian di bagian pendaftaran setelah di screening kemudian pasien akan di arahkan ke bagian pendaftaran untuk mengambil no antrian. Pasien mengambil no antrian, setelah mengambil no antrian pasien di arahkan ke perawat terlebih dahulu. Perawat, di tensi dulu sebelum mendapatkan pelayanan dari dokter setelah di tensi akan di arahkan oleh perawat untuk menunggu panggilan dari dokter sesuai no antrian. Poliklinik, pasien akan mendapatkan pelayanan oleh dokter setelah beres di periksa dokter 
akan mengarahkan ke bagian farmasi untuk mengambil obat. Farmasi, pasien mengambil obat di bagian farmasi setelah itu pasien pulang.

\section{Alur pelayananpendaftaran online}

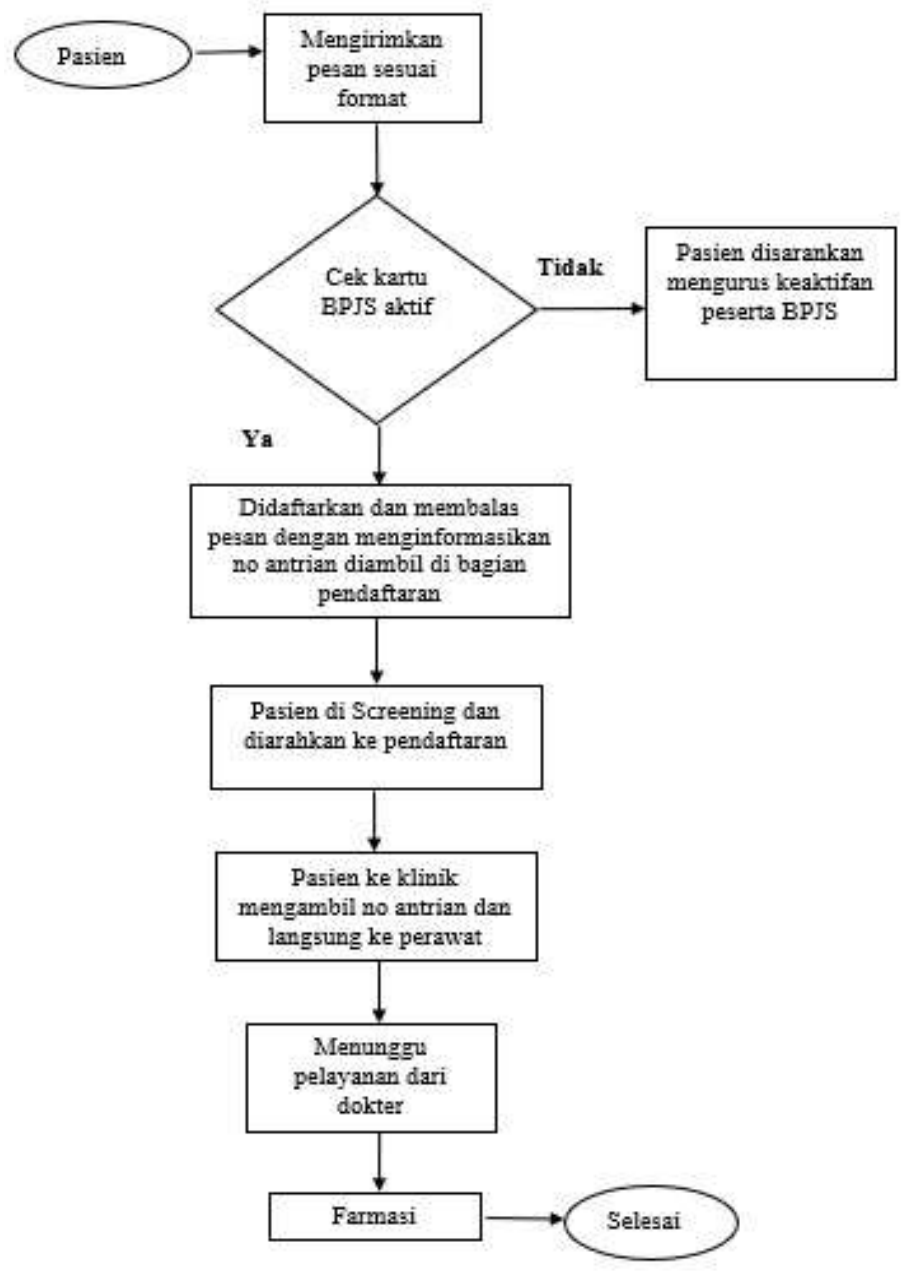

Gambar 1. Alur Pendaftaran Online

Tabel 3. SOP Pelayanan Rekam Medis

\begin{tabular}{|c|c|c|c|}
\hline \multirow{5}{*}{$\begin{array}{l}\text { Klinik X Kota } \\
\text { Bandung }\end{array}$} & \multicolumn{2}{|r|}{ PELAYANAN REKAM MEDIS } & \\
\hline & \multirow{4}{*}{ SOP } & $\begin{array}{l}\text { No Dokumen : } \\
\text { MA/KPMA-01/023/050/XII/2018 }\end{array}$ & \\
\hline & & No Revisi : 00 & \\
\hline & & Tanggal Terbit : 21 Juni 2021 & \\
\hline & & Halaman : 1-2 & \\
\hline \multirow{3}{*}{$\begin{array}{l}\text { Klinik X Kota } \\
\text { Bandung }\end{array}$} & & & dr. Anggia \\
\hline & & & \\
\hline & & & NIP 1190550 \\
\hline 1. Pengertian & $\begin{array}{l}\text { Pelayan } \\
\text { beroren } \\
\text { pulang }\end{array}$ & $\begin{array}{l}\text { rekam medis adalah suatu proses lay } \\
\text { pasien pada saat pasien datang bero }\end{array}$ & $\begin{array}{l}\text { klinis yang } \\
\text { ngga pasien }\end{array}$ \\
\hline
\end{tabular}




\begin{tabular}{cll}
\hline 2. & Tujuan & $\begin{array}{l}\text { Sebagai acuan penerapan langkah-langkah pelayanan rekam medis } \\
\text { untuk menilai dan melengkapi isi rekam medis }\end{array}$ \\
\hline 3. Kebijakan & $\begin{array}{l}\text { Surat keputusan penanggung jawab Klinik X Kota Bandung nomor } \\
\text { 208/MA/KPMA-01/SK-PJ/VII/2021 Tentang Layanan Klinis yang } \\
\end{array}$ & Berorientasi Pasien \\
\hline
\end{tabular}

4. Referensi

$\begin{array}{lr}\text { 5. Langkah- } & \text { Alat dan bahan } \\ \text { langkah } & \text { 1. Kartu BPJS } \\ & \text { 2. Komputer } \\ & \text { 3. Hp }\end{array}$

Petugas pendaftaran yang melaksanakan

Langkah-langkah

1. Pasien daftar ke whataspp no pendaftaran, mengirimkan kartu BPJS

2. Menanyakan apakah pasien pernah berobat kesini atau tidak, jika pasien baru maka petugas pendaftaran memasukan data identitas pasien ke MAC system

3. Petugas pendaftaran mendaftarkam pasien ke dokter yang praktek setelah itu mengirimkan no antrian dan di arahkan untuk di ambil di pendaftaran

4. Petugas kesehatan menerima pasien (mengecek suhu dan meminta pasien melakukan hand hygiene) kemudian mengarahkan pasien ke bagian pendaftaran

5. Petugas pendaftaran

a. Menerima pasien dan melakukan 3S (Senyum,Salam,Sapa)

b. Melakukan identifikasi pasien sesuai SOP identifikasi pasien

c. Meminta pasien memperlihatkan antrian pendaftaran yang sudah di lakukan di pendaftaran online

d. Memberikan no antrian pendaftaran pasien

6. Petugas Rekam Medis

a. Petugas rekam medis menerima pasien berobat dari pendaftaran dan di lihat di MAC

b. Petugas rekam medis memberikan memberikan penomoran pada rekam medis

c. Petugas rekam medis membuat rekam medis pasien dan melengkapi pencatatan kelengkapan rekam medis pasien

d. Petugas rekam medis mendistribukan rekam medis sesuai poli yang di tuju

e. Setelah selesai pelayanan, rekam medis di input untuk pengkodingan oleh petugas pendaftaran

f. Setelah pengkodingan, petugas rekam medis mengecek kelengkapan pencatatan rekam medis

g. Petugas rekam medis memasukan kembali rekam medis pasien pasien ailing ailing sesuai no rekam medisnya

Jika pasien lama, petugas pendaftaran memasukan no kartu BPJS untuk di cari di database MAC system

1. Petugas Rekam Medis menerima pasien berobat dari pendaftaran dan di lihat di MAC system 
2. Petugas rekam medis membuat rekam medis pasien dan melengkapi pencatatan kelengkapan rekam medis

3. Petugas rekam medis mendistribusikan rekam medis sesuai poli yang di tuju

4. Setelah selesai pelayanan, rekam medis di input untuk pengkodingan oleh petugas pendaftaran

5. Setelah pengkodingan, petugas rekam medis mengecek kembali kelengkapan pencatatan rekam medis

6. Petugas rekam medis memasukan kembali rekam medis pasien ailing ailing sesuai no rekam medisnya
A. Unit Seluruh unit Terkait

B. Rekaman historis perubahan

\section{Alur Pelayanan Konsultasi Online}

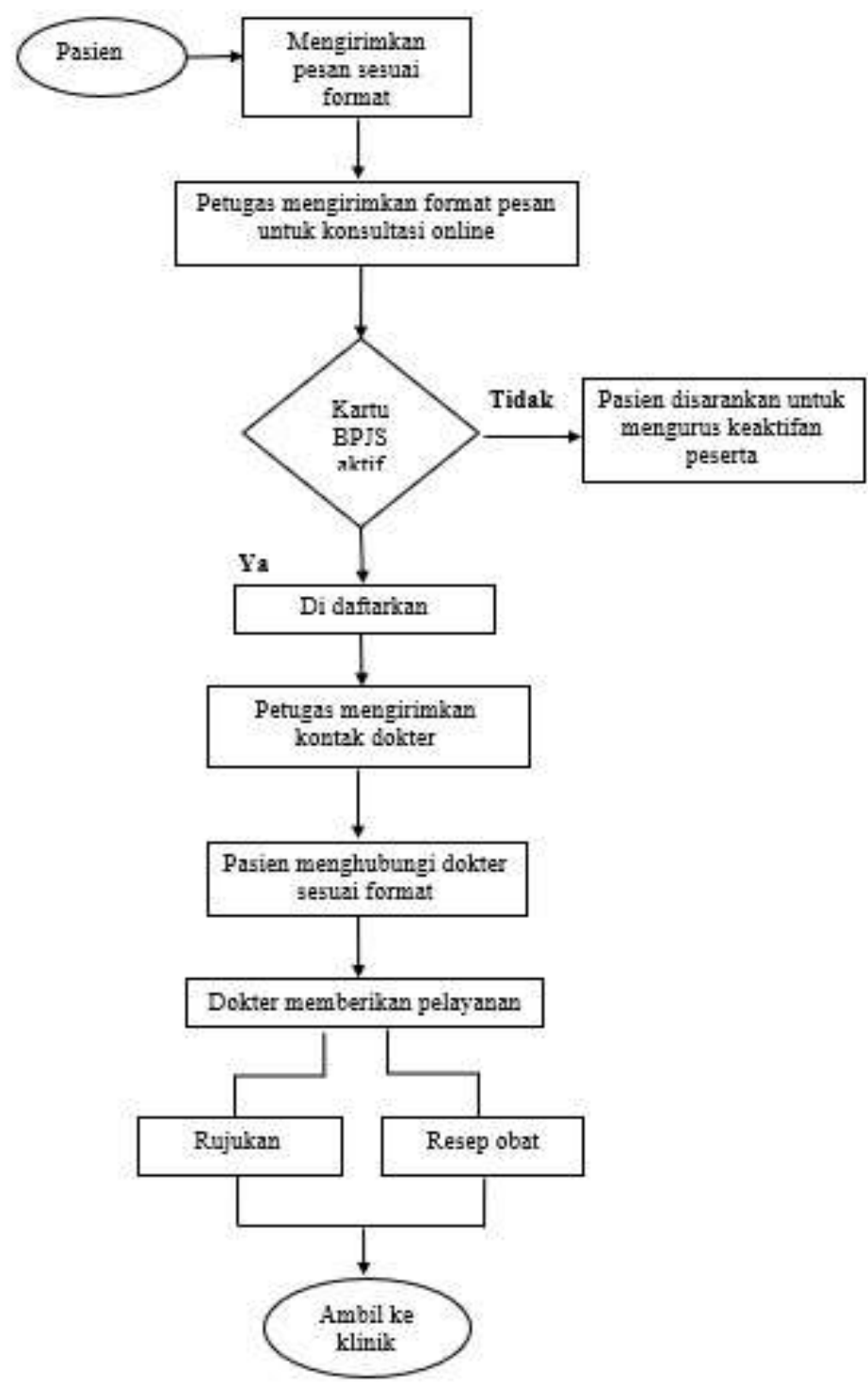

Gambar 2. Alur Pelayanan Konsultasi Online 


\section{SOP}

Dalam hal ini petugas tenaga medis dan perawat harus menggunakan pedoman pada kebijakan yang ada pada kebijakan direktur di Klinik X Kota Bandung 208/MA/KPMA-01/SK-PJ/XII/2021 di jelaskan bahwa : tentang layanan klinis yang berorentasi setiap dokter atau petugas tenaga kesehatan harus memberikan pelayanan rekam medis terhadap pasien dan wajib membuat rekam medis pasien, petugas rekam medis menerima pasien berobat dari pendaftaran harusdan di lihat di MAC, petuga rekam medis membuat rekam medis pasien tersebut dan melengkapinya setelah pasien menerima pelayanan, petugas rekam medis akan mendistribusikan rekam medis pasien sesuai poli yang dituju, pembuatan rekam medis pasien di lakukan melalui dari pencatatan dan dokumentasi pasien dari hasil pemeriksaan, tindakan, pengobatan, dan pelayanan yang di berikan kepada pasien, setiap pencatatan harus di bubuhi nama, tandatangan dokter, dokter gigi atau tenaga kesehatan yang memberikan pelayanan, dan waktu (tanggal atau jam), setelah pelayananan rekam medis di input untuk di koding, petugas rekam medis akan mengecek kembali kelengkapan pencatatan dokumen rekamedisnya dan setelah itu petugas rekam medis akan menyimpan kembali rekam medis pasien ke rak penyimpanan/filling.

SOP Pelayanan merupakan alur pemberian pelayanan rekam medis dari mulai pasien di terimanya berobat hingga mendapatkan pelayanan dari tenanga kesehatan untuk mengambil data pasien yang disimpan di intalasi rekam medis. SOP tersebut diberikan agar proses pelayanan tersebut dapat tercatat baik dan dapat di pertanggung jawabkan dengan baik sesuai dengan SOP-nya .

SOP Pencatatan merupakan tata cara pencatatan oleh petugas kesehatan dalam memberikan pelayanan dan tindakan siapa saja yang berhak memberikan catatan rekam medis. Dalam pencatatan petugas rekam medis memerlukan 2 kali kinerja karena harus melakukan peralihan manual ke sistem elektronik tetapi SOP pencatatan belum memenuhi standar karena masih ada beberapa dokter tidak mengisi rekam medis pasien konsultasi online oleh karena itu petugas bagian koding akan kesulitan untuk mengkoding rekam medis pasien.

SOP penyimpanan merupakan tata cara yang digunakan oleh pihak internal intalasi rekam medis dalam penyimpanan dokumen rekam medis dengan pertimmbangan kualitas pelayanan. Pada penyimpanan rekam medisnya belum memenuhi standar karena Klinik X ini di ruangan penyimpanan rekam medis pasien tidak menggunakan tracer, bon peminjaman, out guide dan sering terjadi kehilangan dokumen rekam medis pasien. Oleh karena itu ini petugas bagian filling akan mengalami kesulitan dalam mencari rekam medis pasien dan mengembalikan rekam medis pasien ke rak penyimpanan (Suhartina, 2019).

\section{Penyimpanan Rekam Medis}

Berdasarkan hasil observasi yang di dapatkan di Klinik X Kota Bandung ini dari bulan April-Mei 2021 sistem penyimpanan rekam medis menggunakan sentralisasi (Ritonga, 2020) dan Klinik X ini tidak menggunakan tracer, bon peminjaman, out guide dan sering terjadi hilang dokumen rekam medis pasien di ruangan penyimpan/filling sehingga pasien mendapatkan pelayanannya akan terlambat karena membutuhkan waktu lama untuk melakukan pencarian dokumen rekam medis pasien yang tidak ada di rak penyimpanan rekam medis karena tidak tahu apakah dokumen rekam medinya masih diluar atau di pinjam oleh poli. 


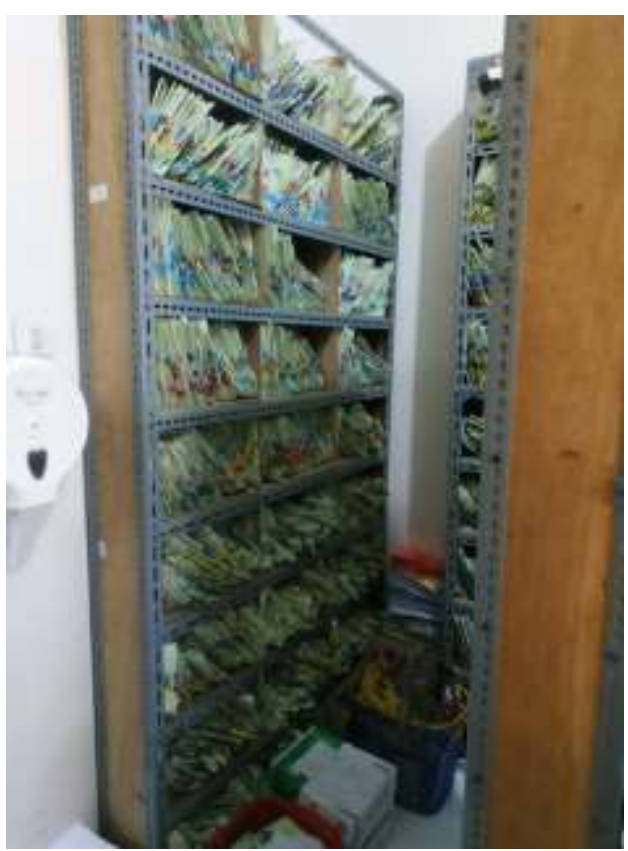

Gambar 3. Ruangan Penyimpanan Rekam Medis

Ruangan penyimpanan dokumen rekam medis Klinik X Kota Bandung rak untuk penyimpan dokumen rekam medisnya masih kurang karena masih banyak dokumen rekam medis pasien yang disimpan diatas lantai sehingga terjadi penumpukkan (Nugraheni, 2015) terutama rekam medis pasien yang berobat konsultasi online yang di ambil oleh petugas rekam medis dari rumah dokter tidak langsung disimpan ke dokumen rekam medis pasien tapi malah diletakan di atas rak penyimpanan sehingga takut terjadi hilang jika terus dibiarkan terlalu lama.

Perbaharuan terhadap pelayanan rekam medis rawat jalan pada masa pandemi COVID-19 di Klinik X Kota Bandung terjadi banyak perubahan selama masa pandemi COVID-19 dari mulai pengurangan jam kerja operasional pelayanan kesehatan sehingga beban kerja tenaga rekam medis bertambah dan jumlah pasien yang melakukan berobat jalan ke Klinik X Kota Bandung ini terjadi penurunan. Berbeda dengan penelitian Analisis Sistem Pelayanan Rekam Medis Rawat Inap di RSUP Dr. Kariadi Semarang jumlah pasien rawat inap semakin bertambah (Dewi, 2017).

Di masa pandemi Klinik X Kota Bandung menerapkan protokol kesehatan yaitu guna untuk memutuskan mata rantai penyebaran COVID-19 untuk itu pasien yang melakukan pendaftaran langsung ke Klinik $\mathrm{X}$ ini masih di layani tetapi pasien terlebih dahulu harus melakukan pengecekan suhu dan di screening oleh petugas kesehatan untuk memberikan pelayanan kesehatan yang terbaik di masa pandemi harus sesuai dengan protokol kesehatan. Oleh karena itu fasilitas kelengkapan selama masa pandemi di rumah sakit mulai adanya handsanitazer, petugas kesehatan yang memakai masker dan memakai sarung kepala, hingga persedian masker untuk petugas kesehatan (Wahyuni \& Setijaningsih, 2021).

\section{KESIMPULAN}

Berdasarkan hasil penelitian dan pembahasan dapat di simpulkan bahwa Klinik X Kota Bandung pelayanan rekam medis selama masa pandemi ini sudah menggunakan digitalisasi yaitu bisa melakukan pelayanan pendaftaran online lewat whatsapp untuk mengurangi antrian yang cukup panjang tetapi penerimaan pasiennnya terlambat karena 
masih ada beberapa pasien yang datang mengeluh tidak mendapatkan pelayanan pendaptaran online, dan bagi pasien yang tidak bisa datang ke Klinik juga bisa melakukan konsultasi online dengan doker via whatsapp tetapi pelayanannya dari dokternya terlambat oleh karena itu pasien harus sabar untuk mendapatkan pelayanan dari dokter. Faktor penyebab terjadinya keterlambatan dalam penerimaan pendaftaran online dan konsultasi online yaitu karena Klinik X ini belum menggunakan sistem aplikasi hanya menggunakan whatsapp sehingga tidak memakai no antrian oleh karena itu petugas pendaftaran dan dokter harus merespon chat pasien dari bawah oleh karena itu perlu di perbaiki lagi supaya dengan menggunakan aplikasi pada pelayanan konsultasi online dan pendaftaran online supaya no antrian pasien jelas.

Pada penyimpanan rekam medis Klinik $\mathrm{X}$ tidak menggunakan tracer, bon peminjaman dan out guide oleh karena itu petugas sering mengalami kesulitan dalam mencari dokumen rekam medis pasien yang hilang di rak penyimpanan sehingga pasien mendapatakan pelayanan selanjutnya akan terlambat. Standar Operasional Prosedur (SOP) di Klinik X ini belum memenuhi standar atau belum efektif karena masih ada beberapa bagian yang belum lengkap.

\section{BIBLIOGRAFI}

Ali, P. B., \& et al. (2018). Penguatan Pelayanan Kesehatan Dasar di Puskemas. In Direktorat Kesehatan dan Gizi Masyarakat.

Asriati, Y. (2021). Beban Kerja Pelayanan Rekam Medis Di Masa Pademi COVID-19. Jurnal Manajemen Informasi Dan Administrasi Kesehatan, 3(2). https://doi.org/10.32585/jmiak.v3i2.1019

Creswell, J. . 2016. (2016). Research Design, Pendekatan Metode Kualitatif, Kuantitaif, dan Campuran. Yogyakarta: Pustaka Belajar.

Hidayati, M., \& Dewi, R. M. (2018). Pengaruh Kelengkapan Formulir Resume Medis Rawat Inap Terhadap Mutu Rekam Medis Di Rsud Kabupaten Sumedang. Jurnal INFOKES (Informasi Kesehatan), 2(2), 72-82.

Hukum, P., Dalam, P., Konsultasi, L., \& Online, K. (2021). Jurnal hukum kesehatan indonesia. 01(01), 1-10.

Irianti, B., Fadly, F., \& Nursta'adah, U. (2021). Mendekatkan Pelayanan Bidan Dalam Masa COVID-19 (Konsultasi Online Kebidanan Pada Masa Pandemik). Prosiding Penelitian Pendidikan Dan Pengabdian 2021, 1(1), 1119-1125.

Ismail, R. Y. (2020). Penerapan Prinsip Indemnitas Terhadap Penolakan Klaim Asuransi Atas Tidak Terpenuhinya Rekam Medis Dihubungkan Dengan Kuhd Jo Permenkes Nomor 269/Menkes/Per/Iii/2008. Fakultas Hukum Unpas.

Kemenkes. (2019). Peraturan menteri kesehatan republik indonesia nomor 20 tahun 2019 tentang penyelenggaraan pelayanan. April 2005, 3.

Nugraheni, R. (2015). Analisis Pelayanan Rekam Medis Di Rumah Sakit X Kediri Jawa Timur Analysis Services Medical Record in Bhayangkara Hospitals Kediri-East Java. Jurnal Wiyata, 2(2), 169-175.

Nuraini, N. (2015). Analisis Sistem Penyelenggaraan Rekam Medis di Instalasi Rekam Medis RS “ X ” Tangerang Periode April-Mei 2015. Jurnal Administrasi Rumah Sakit, 1(2), 147-158. http://dx.doi.org/10.7454/arsi.v1i3.2180

Organization, W. H. (2020). Considerations for quarantine of individuals in the context of containment for coronavirus disease (COVID-19): interim guidance, 19 March 2020. World Health Organization.

Permenkes, R. I. (2008). Peraturan Menteri Kesehatan Republik Indonesia No. 269/MenKes/Per/III/2008 tentang Rekam Medis. Jakarta: Kementerian Kesehatan RI.

Permenkes RI. (2008). permenkes ri 269/MENKES/PER/III/2008. In Permenkes Ri No 
269/Menkes/Per/Iii/2008 (Vol. 2008, p. 7).

Rendarti, R. (2019). Faktor-Faktor yang Mempengaruhi Mutu Pelayanan Rekam Medis di Rumah Sakit. Surya Medika: Jurnal Ilmiah Ilmu Keperawatan Dan Ilmu Kesehatan Masyarakat, 14(2), 59. https://doi.org/10.32504/sm.v14i2.125

Ritonga, Z. A., \& Wannara, A. J. (2020). Faktor-faktor Penyebab Keterlambatan Waktu Penyediaan Rekam Medis Rawat Jalan di Rumah Sakit Umum Madani Tahun 2019. Jurnal Ilmiah Perekam Dan Informasi Kesehatan Imelda (JIPIKI), 5(1), 85-97. https://doi.org/10.2411/jipiki.v5i1.341

Suhartina, I. (2019). Analisis Efektivitas SOP Pelaksanaan Penyimpanan Berkas Rekam Medis Di Puskesmas Lawang. Jurnal Manajemen Informasi Kesehatan Indonesia (JMIKI), 7(2), 128. http://dx.doi.org/10.33560/jmiki.v7i2.226

Wahyuni, N., \& Setijaningsih, R. A. (2021). Manajemen Pelayanan Pendaftaran Pasien Tppgd Dalam Rangka Pencegahan Penularan COVID-19 Di Rs X Tahun 2021. Prosiding Diskusi Ilmiah" Inovasi Dan Teknologi Informasi Untuk Mendukung Kinerja PMIK Dalam Masa Pandemi COVID 19".

Wibowo, A. A., Pribadi, F., Medis, R., \& Prosedur, S. O. (2017). Optimalisasi Pelayanan Rekam Medis Berdasarkan Abstrak. $x$.

(C) 2021 by the authors. Submitted for possible open access publication under the 